\title{
STRATEGIES OF LEARNING SPEAKING SKILL BY INDONESIAN LEARNERS OF ENGLISH AND THEIR CONTRIBUTION TO SPEAKING PROFICIENCY
}

\author{
Junaidi Mistar \\ (junaidimistar@hotmail.com) \\ Atik Umamah \\ (atik.umamah@yahoo.com) \\ Universitas Islam Malang \\ Jl. MT Haryono 193 Malang, Indonesia 65144
}

\begin{abstract}
This paper was a subset report of a research project on skill-based English learning strategies by Indonesian EFL learners. It focusses on the attempts to reveal: (1) the differences in the use of strategies of learning speaking skill by male and female learners, and (2) the contribution of strategies of learning speaking skill on the learners' speaking proficiency. The data from 595 second year senior high school students from eleven schools in East Java, Indonesia were collected using a 70 item questionnaire of Oral Communication Learning Strategy (OCLS) and a 10 item self-assessment of speaking proficiency. The statistical analysis revealed that gender provided significant effects on the intensity of use of six types of strategies of learning speaking skill - interactional-maintenance, self-evaluation, fluency-oriented, time gaining, compensation, and interpersonal strategies - with female learners reporting higher intensity of use. A further analysis found that four strategy types - interactional-maintenance, self-improvement, compensation, and memory strategies - greatly contribute to the speaking proficiency. These findings imply that strategies-based instruction, covering the four most influential strategies, needs to be integrated explicitly in the speaking class to help learners, particularly male learners, cope with problems in learning speaking skill.
\end{abstract}

Keywords: learning strategies, speaking skill, gender, proficiency 
Learning strategies have been worldwide issues in English language teaching and have drawn considerable attention from scholars in the last few decades. It is proven by dozens of studies which have been carried out to get deep insight into many aspects of learning strategies, particularly when Oxford (1990) came up with a questionnaire to assess language learning strategies called Strategy Inventory for Language Learning (SILL). It has been translated into many languages and used in many different countries around the world. Some of the studies try to profile the use of strategies by different groups of learners of English such as Indonesian (Lengkanawati, 1997), French (Merrifield, 1996), Taiwanese (Lan \& Oxford, 2003), Japanese (Mochizuki, 1999), and Singaporean (Wharton, 2000). Some others pose learning strategies as predictors of learning success (Mistar, 2011a; Thomson \& Rubin, 1996), and still some others pose learning strategies as criterion variables predicted from a number of other variables such as gender, proficiency level, motivation, personality, and language aptitude (Oxford \& Ehrman, 1995; Huda, 1998).

In recent years, the focus of the studies has shifted to a narrower scope that is on the strategies in developing a specific language skill, such as speaking, writing, reading, and listening. In the area of speaking skill, some studies use theories of learning strategies as their theoretical bases and they use Oxford's SILL as the key instrument. Cabaysa and Baetiong (2010), for example, demonstrated that Filipino students prefer metacognitive, social/ affective, and compensation strategies in speaking class. Meanwhile, achievement in school, attitudes towards speaking English, tasks at hand, topics of discourse and teacher's techniques are considered to be influential factors to strategy choice. In Indonesian context, Umamah (2008) and Novitasari (2009) found students with higher speaking proficiency use social strategies more frequently than students with lower speaking proficiency. On the contrary, Wahyuni (2013) reported that the correlation between overall speaking strategy use and speaking proficiency is not significant, though positive. However, the effect of gender on strategy preference is found significant on affective strategies.

Other studies use communication strategies as their theoretical bases. Nakatani (2006), for example, studied the relationship between English proficiency and the use of communication strategies among EFL learners in Japan and found that learners with higher proficiency reported more use of socialaffective, fluency-maintaining, and negotiation-for-meaning strategies than did learners with middle and lower proficiency level. Moriam (2005), who investigated Japanese and Bangladeshi university students, found that Bangladeshi 
employ cognitive and interpersonal strategies more than Japanese, and that gender difference of both groups provides insignificant effect of the use of speaking strategies, except that cognitive strategies used by Japanese females are found to be higher than those by the male. Another influential research (Khan, 2010) found that among Spanish university students task characteristics are more influential to the use of speaking strategies than proficiency. A more specific research was done by Monjezi (2014), who examined the effects of gender and proficiency on the compliments and compliment responses made by Iranian learners. Supporting most of research results, this investigation indicates that gender and proficiency have a significant impact on spoken production.

The findings of the studies as reviewed above indicate that the effect of gender on the choice of speaking strategies is not yet conclusive and that the correlation between speaking strategies and speaking proficiency is not yet clear. Thus, further investigation on the matter needs to be carried out. It is for these purposes that the present study was carried out. However, instead of using either learning strategies or communication strategies as a theoretical foundation, the present study used both. The identification of the strategies of learning speaking skill, the intensity of use, and the difference in the strategy use by successful and less successful learners have been reported elsewhere (Mistar, Zuhairi \& Umamah, 2014). Thus, the present paper focuses on finding the answer to the questions: 1) does gender difference affect the use of strategies of learning speaking skill, and 2) does the use of strategies contribute to speaking skill?

\section{METHOD}

The research problems of the present study contained comparative and correlational elements. The former is in the form of a comparison between female and male learners in their use of strategies of learning speaking skill and the latter is in the form of the correlation between the students' use of strategies and their speaking skill. Thus, the study employed both ex-post facto and correlation designs. The ex-post facto design was used for finding the answer to the first research problem and the correlation design was used to get the answer to the second research question.

In fact 743 second year students coming from eleven senior high schools from eleven regencies in East Java, Indonesia participated in the research pro- 
ject. The schools were selected on the basis of accessibility and ease of bureaucracy. However, as the female learners outnumbered the male learners very highly, the number of female learners was substantially reduced so that the data from 595 students consisting of 328 (55\%) female and $267(45 \%)$ male were analyzed for the present report of the study. At the time of data collection, the students had been learning English in their formal schooling for nearly five years. This is so because in Indonesian schooling system English starts to be officially taught as a compulsory school subject to students in the junior high school level which lasts for three years. The goal of English teaching is to develop the communicative competence of the students as indicated in the ability to use English as a means of communication. As such, the four macro skills of English including speaking, listening, writing, and reading are taught equally in an integrative mode around specific genres.

The subjects were requested to complete a questionnaire of Oral Communication Learning Strategy (OCLS) derived from learning strategy items (Oxford, 1990) and communication strategy items (Khan, 2010; Lopez, 2011; Nakatani, 2006). The questionnaire is of Likert-type, requiring the subjects to respond to each item using a 5-point scale ranging from 1, which means never or almost never true of me, to 5, which means always or almost always true of me. Originally 85 items were prepared; however, based on the result of construct validity analysis only 70 items were found to contribute validly to the assessment of strategies to learn speaking skill. The analysis of its reliability using Cronbach Alpha method yielded an index of .928, indicating that the data collected by this instrument is very highly reliable. Upon the use of factor analysis, the items were classified into eleven strategy categories, including cognitive interaction maintenance, self-improvement, self-evaluation, fluencyoriented, metacognitive planning, time gaining, resources-based, compensation, interpersonal, affective, and memory strategis (Mistar, Zuhairi \& Umamah, 2014).

In addition to the questionnaire, a 10 item self-assessment of speaking skill was also used. In this case, the subjects were exposed to 10 speaking acts such as I can tell the plot of a film that I watch in English and I can tell my future ambitions in life in English. Then, they were asked to assess how well they were able to perform each speaking act and provide a response on a 1 to 5 range, with 1 meaning not at all, 2 with much difficulty, 3 with some difficulty, 4 with very little difficulty, and 5 easily. Self-assessment is considered reliable 
and valid as it correlates significantly with actual language proficiency (Bachman \& Palmer, 1989; Mistar, 2011b).

The data analysis was carried out statistically using SPSS 20. Firstly, independent samples t-tests were performed to compare the use of the eleven strategy categories by female and male learners. Secondly, a standard multiple regression analysis was performed to measure the relationship between the use of these eleven strategy categories and the students' perceived speaking skill as well as to assess the significance of each of the eleven predictors of speaking skill.

\section{FINDINGS AND DISCUSSION}

\section{Findings}

\section{Question 1: Does gender difference affect the use of strategies of learning speaking skill?}

The results of the statistical analysis of the comparison in the use of strategies of learning speaking skill by female and male learners are summarized in Table 1. As the table shows, out of eleven strategy categories, eight categories were found to be used more frequently by female learners and the other three were used more frequently by male learners. Female learners were found to use self-evaluation strategies the most frequently $(\mathrm{M}=3.45)$, while male learners reported resources-based strategies as the most frequently used strategies $(\mathrm{M}=3.47)$.

A further analysis on the significance of the difference in the use of each strategy category, however, reveals that among the eight strategy categories reported being used more frequently by female learners, only six were used at significantly different intensity, including cognitive interaction maintenance strategies $(\mathrm{p}<.020)$, self-evaluation strategies $(\mathrm{p}<.005)$, fluency oriented strategies $(\mathrm{p}<.015)$, time gaining strategies $(\mathrm{p}<.012)$, compensation strategies $(\mathrm{p}<.045)$, and interpersonal strategies $(\mathrm{p}<.002)$. The intensity of use of the other two strategy categories, however, were found to be insignificantly different, including self-improvement strategies $(\mathrm{p}<.370)$ and metacognitive planning strategies $(\mathrm{p}<.139)$. Meanwhile, among the three strategy categories which were reported to be used with higher intensity by male learners, none was found to be 
significant with $\mathrm{p}$ values being less than $.727, .295$, and .865 for resourcesbased, affective, and memory strategies respectively.

Table 1. The Difference in the Use of Strategies of Learning Speaking Skill by Female Learners $(\mathrm{N}=328)$ and Male Learners $(\mathrm{N}=\mathbf{2 6 7})$

\begin{tabular}{|c|c|c|c|c|}
\hline Strategy Categories & Gender & Mean (s.d) & $\begin{array}{l}\text { Mean } \\
\text { Differ- } \\
\text { ence }\end{array}$ & t-value*) \\
\hline \multirow[t]{2}{*}{ Overall Strategies } & Female & $3.19(.53)$ & .09 & $2.023(\mathrm{p}<.044)$ \\
\hline & Male & $3.10(.50)$ & & \\
\hline \multirow{2}{*}{$\begin{array}{l}\text { Cognitive Interaction } \\
\text { Maintenance Strat. }\end{array}$} & Female & $3.35(.64)$ & .12 & $2.327(\mathrm{p}<.020)$ \\
\hline & Male & $3.23(.59)$ & & \\
\hline \multirow[t]{2}{*}{ Self-Improvement Strategies } & Female & $2.83(.65)$ & .05 & $.897(\mathrm{p}<.370)$ \\
\hline & Male & $2.78(.63)$ & & \\
\hline \multirow[t]{2}{*}{ Self-Evaluation Strategies } & Female & $3.45(.67)$ & .16 & $2.809(\mathrm{p}<.005)$ \\
\hline & Male & $3.29(.67)$ & & \\
\hline \multirow[t]{2}{*}{ Fluency-Oriented Strategies } & Female & $2.96(.81)$ & .15 & $2.441(\mathrm{p}<.015)$ \\
\hline & Male & $2.81(.73)$ & & \\
\hline \multirow{2}{*}{$\begin{array}{l}\text { Metacognitive Planning } \\
\text { Strategies }\end{array}$} & Female & $3.16(.74)$ & .09 & $1.480(\mathrm{p}<.139)$ \\
\hline & Male & $307(66)$ & & \\
\hline \multirow[t]{2}{*}{ Time Gaining Strategies } & Female & $3.32(.71)$ & .14 & $2.516(\mathrm{p}<.012)$ \\
\hline & Male & $3.18(.69)$ & & \\
\hline \multirow[t]{2}{*}{ Resources-Based Strategies } & Female & $3.44(.75)$ & -.03 & $-.350(\mathrm{p}<.727)$ \\
\hline & Male & $3.47(.78)$ & & \\
\hline \multirow[t]{2}{*}{ Compensation Strategies } & Female & $3.36(.80)$ & .13 & $2.010(p<.045)$ \\
\hline & Male & $3.23(.74)$ & & \\
\hline \multirow[t]{2}{*}{ Interpersonal Strategies } & Female & $3.41(.81)$ & .20 & $3.076(\mathrm{p}<.002)$ \\
\hline & Male & $3.21(.77)$ & & \\
\hline \multirow[t]{2}{*}{ Affective Strategies } & Female & $2.92(.78)$ & -.07 & $\begin{array}{l}-1.048 \\
(\mathfrak{p}<.295)\end{array}$ \\
\hline & Male & $2.99(.67)$ & & \\
\hline \multirow[t]{2}{*}{ Memory Strategies } & Female & $2.85(.74)$ & -.01 & -.170 \\
\hline & Male & $2.86(.69)$ & & \\
\hline
\end{tabular}

*) two-tailed test 


\section{Question 2: Does the use of strategies of learning speaking contribute to speaking skill?}

To assess the contribution of the eleven strategy categories to speaking skill, a standard regression analysis was performed and the result is presented in Table 2. As the table shows, the multiple correlation coefficient (Multiple R) is .348 with the adjusted R Square being .104, indicating that $10.4 \%$ of the students' speaking skill variance are attributable to their strategies of learning speaking. The explained proportion of variance of speaking skill was found to be significant since the analysis found an F-value $7.290(\mathrm{p}<.000)$.

A further analysis of the relative importance of each of the eleven types of strategies revealed that four strategy types significantly affected the students' speaking skill. In this regard, cognitive interaction maintenance strategies, selfimprovement strategies, and compensation strategies provided positive contribution with $\mathrm{t}$-values being $2.772(\mathrm{p}<.006), 2.080(\mathrm{p}<.038)$, and $2.451(\mathrm{p}<.015)$ respectively. Meanwhile, memory strategies contributed negatively with a tvalue being $-2.266(\mathrm{p}<.024)$.

Table 2. Regression Analysis of the Predictability of Speaking Skill from Learning Strategies

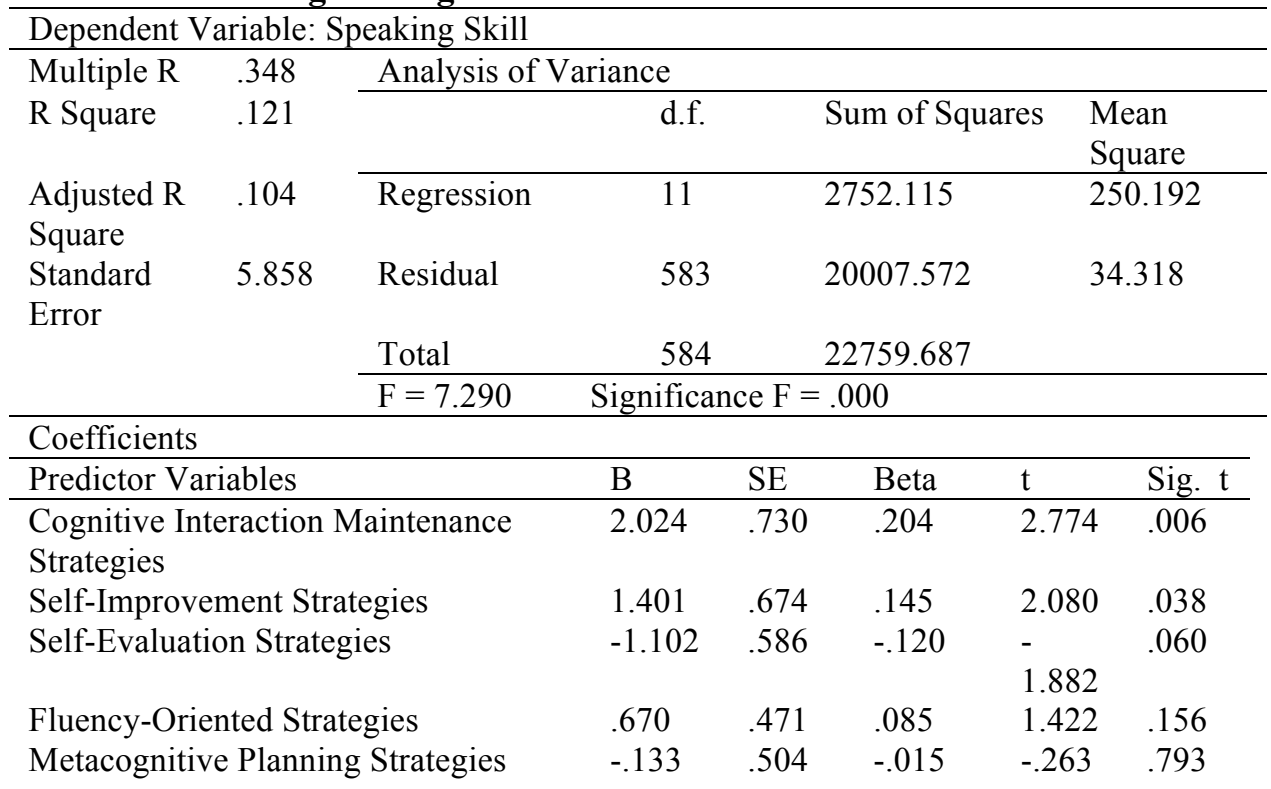




\begin{tabular}{llllll} 
Time Gaining Strategies & .133 & .485 & .015 & .275 & .783 \\
Resources-Based Strategies & .218 & .378 & .027 & .575 & .565 \\
Compensation Strategies & .992 & .405 & .124 & 2.451 & .015 \\
Interpersonal Strategies & -.172 & .378 & -.022 & -.454 & .650 \\
Affective Strategies & .316 & .424 & .038 & .744 & .457 \\
Memory Strategies & -1.037 & .458 & -.120 & - & .024 \\
Constant & & & & 2.266 & \\
\hline
\end{tabular}

\section{Discussion}

Generally speaking, the present study confirms that gender difference brings about differences in the strategy use and that the contribution of learning strategies to speaking skill is significant. Though some studies fail to prove that female and male learners use different strategies in their second or foreign language learning (Cabaysa \& Baetiong, 2010; Lunt, 2000; Moriam, 2005; Wahyuni, 2013), the majority of studies supports the significant effect of gender on strategy use. Kaylani's (1996) finding also revealed that females used more strategies than males did. In her study involving 255 high school students in Jordan, she found that female learners used significantly more memory, cognitive, compensation, and affective strategies than did male learners. Furthermore, in a study with Turkish learners of English Aslan (2009) reported that female learners used direct strategies, including memory, cognitive, and compensation strategies and indirect, including metacognitive, affective, and social strategies more frequently than did male learners. In a more recent study of speaking strategies, Monjezi (2014) also reported the significant effect of gender on the compliments and compliment responses made by Iranian learners. In this case, the researcher revealed that there is significant gender difference in making and responding compliments, and female students reported to have more various compliments and responses than their male counterparts.

In the studies that fail to provide evidence of the effect of gender on overall strategy use, parts of the findings still support the significant effect of gender. Moriam (2005), for example, reported that, even though the use of overall learning strategies was not affected by gender difference, Japanese female learners were found to use cognitive strategies more frequently than did male learners. In addition, Wahyuni (2013) came up with a conclusion that among 
Indonesian learners of English gender difference affects the use of affective strategies, with female learners reporting higher use.

When comparisons were made in the use of each strategy type, the present study found that females reported higher use of eight strategy types. However, significant differences were found in the use of six strategy categories, including cognitive interaction maintenance strategies, self-evaluation strategies, fluency-oriented strategies, time gaining strategies, compensation strategies, and interpersonal strategies with female learners reporting higher use. In this case, the strongest difference appeared in the use of interpersonal strategies $(p<.002)$ covering two items: telling the speaking partner if they do not understand and asking to repeat or explain in different ways what they do not understand. It implies that female learners are more expressive and open in expressing their difficulty in learning speaking. The reason for this might be explained by Kimura (1999), who noted that females do better than males in verbal memory and verbal fluency.

That female learners self-evaluate better and are more fluency oriented may stand as an explanation for the superiority of females over males in their English proficiency. Aslan (2009), for example, reported that female learners in a Turkish university outperformed male learners in their English learning. Yan (2009) also found that Chinese female learners excelled male learners in their language learning.

The insignificant difference in the use of self-improvement strategies implies that the two groups of students share almost the same strategies at the same level of frequency. Both groups seem to have been aware of the paramount importance of English as a global language, though they find it hard to create opportunities to use it in real communication since English is a foreign language in Indonesia. The mean scores of the use of self-improvement strategies are just 2.83 and 2.78 in a $1-5$ scale by female group and male group respectively.

Regarding the contribution of learning strategies to speaking proficiency, this study uncovered that the overall learning strategies provided significant contribution to speaking proficiency, though the variance of the students' speaking skill accounted for by their learning strategies is just $10.4 \%$. Even though some studies failed to provide evidence of the relationship between strategy use and general English proficiency (Lengkanawati, 1997) or between strategy use and speaking performance (Wahyuni, 2013), most studies using either correlation design or experimental design support the significant role of 
strategy use. Djiwandono (1998), for example, studied the correlation between the use of learning strategies in terms of consistency, diversity, and purposefulness, and oral communication proficiency of students in an Indonesian university and found that the two variables were significantly correlated with the diversity of strategy use being the most significant predictor. Cohen, Weaver, and $\mathrm{Li}$ (1996) carried an experiment to study the effect of strategy-based instruction on speaking a foreign language and reported that the experimental group, the one who underwent training sessions on how to use speaking strategies, performed better in the speaking task 'City Description' than the control group. Similarly, Dodour and Robbins (1996) found that Egyptian learners of English who got strategy instruction gained significantly better speaking ability than did learners without strategy instruction. More specifically, Lam (2010) revealed that the effect of communication strategy training on the learners' speaking performance was stronger among students with low proficiency than among students with high proficiency.

When the relative importance of each strategy type was analyzed using regression analysis, cognitive interaction maintenance strategies, selfimprovement strategies, and compensation strategies were found to provide positive contribution to speaking skill, with the first strategy type being the most significant predictor. On the other hand, memory strategies were found to contribute negatively, in the sense that memorization may distract the development of speaking skill. These findings indicate that not all learning strategies positively contribute to learning success in speaking skill; consequently, it is essential for teachers to encourage particularly male learners to use the appropriate strategies to attain success in learning English speaking by explicitly incorporating strategies-based instruction (SBI) covering the three influential strategies in the classroom. Cohen (2000) points out that strategies-based instruction offers students with benefits such as directing them to accomplish task efficiently, promoting autonomous learning outside the classroom, and building confidence in learning and using the target language. In speaking context, some studies (Cohen, 2000; Cohen, Weaver, \& Li, 1996; Nakatani, 2006) have highlighted the significantly positive effect of integrating strategies-based instruction on the improvement of students' oral performance.

Thus, training programs of strategies of learning speaking skill will lead to greater use of the strategies, and the intensive use of strategies of learning speaking skill will in turn lead to better speaking skill. The training programs 
are particularly important for male learners as they use strategies of learning speaking skill lower than do female learners.

\section{CONCLUSIONS AND SUGGESTIONS}

This current study is carried out in an attempt to examine the influence of gender on the strategy preferences and to measure the contribution of learning strategies to speaking proficiency. The statistical analysis shows that gender affects the overall use of learning strategies and further analyses of the difference in the use of each strategy category indicate significant differences in the use of cognitive interaction maintenance, self-evaluation, fluency-oriented, time gaining, compensation, and interpersonal strategies. In this case, female learners are found to use these strategies more intensively. Furthermore, this study proved that, though generally speaking the use of strategies correlate with speaking skill, not all learning strategy categories significantly contribute to students' speaking proficiency since only three strategy types - cognitive interaction maintenance, self-improvement, and compensation strategies - indicate strong contribution. Surprisingly, memory strategies are found to affect speaking skill in a negative manner.

The findings that female learners use the strategies differently from male learners and that the use of strategies contributes to the learners' speaking ability suggest some pedagogical implications. On the one hand, the students of EFL context should be aware of the availability of a number of strategies they may use to learn to speak in English. On the other hand, the teachers need to train students, especially male students, to employ strategies reported to be influential in achieving success in learning speaking skill. This can be done by providing a specific and explicit strategies-based instruction in the speaking class. Thus, research to provide more evidence on the effectiveness of strategy training for developing speaking skill of the learners should be encouraged.

\section{REFERENCES}

Aslan, O. (2009). The role of gender and language learning strategies in learning English. (Master's thesis, Middle East Technical University, Turkey).

Bachman, L. F., \& Palmer, A. S. (1989). The construct validation of selfratings of communicative language ability. Language Testing, 6(1), 14-29. 
Cabaysa, C. C., \& Baetiong, L. R. (2010). Language learning strategies of students at different levels of speaking proficiency. Education Quarterly, 68(1), 16-35.

Cohen, A. (2000). Strategies-based instruction for learners of a second language. NASSP Bulletin, 84, 10-18.

Cohen, A. D., Weaver, S. J., \& Li, T. (1996). The impact of strategies-based instruction on speaking a foreign language. Minnesota: Center for Advanced Research on Language Acquisition, University of Minnesota.

Djiwandono, P. I. (1998). The relationship between EFL learning strategies, degree of extroversion, and oral communication proficiency: A study of second year secretarial students at Widya Karya University. (Doctoral dissertation, IKIP Malang, Indonesia).

Dodour, E. L., \& Robbins, J. (1996). University-level studies using strategy instruction to improve speaking ability in Egypt and Japan. In R. L. Oxford (Ed.), Language learning strategies around the world: Cross-cultural perspectives (pp. 157-166). Honolulu: University of Hawaii Press.

Huda, N. (1998). Relationship between speaking proficiency, reflectivityimpulsivity, and L2 learning strategies. In W. A. Renandya \& G. M. Jacobs (Eds.), Learners and language learning (pp. 40-55). Singapore: SEAMEO Regional Language Center.

Kaylani, C. (1996). The influence of gender and motivation on EFL learning strategy use in Jordan. In R. L. Oxford (Ed.), Language learning strategies around the world: Cross-cultural perspectives (pp. 75-88). Honolulu: University of Hawaii Press.

Khan, S. (2010). Strategies and spoken production on three oral communication task: A study of high and low proficiency EFL learners. (Doctoral Dissertation, Universitat Autonoma de Barcelona, Spain).

Kimura, D. (1999). Sex differences in the brain. Boston: Scientific American, Inc.

Lam, W. Y. K. (2010). Implementing communication strategy instruction in the ESL oral classroom: What do low-proficiency learners tell us? TESL Canada Journal, 27(2), 11-30. 
Lan, R., \& Oxford, R. L. (2003). Language learning strategy profiles of elementary school students in Taiwan. International Review of Applied Linguistics in Language Teaching, 41, 339-379.

Lengkanawati, N. S. (1997). Contribution of learning strategies on language proficiency. (Doctoral dissertation, IKIP Bandung, Indonesia).

López, M. M. (2011). Speaking strategies used by BA ELT students in public universities in Mexico. MEXTESOL Journal, 35(1), 1-22.

Lunt, E. H. (2000). The learning strategies of adult immigrant learners of English: Quantitative and qualitative perspectives. (Ph.D thesis, The University of Melbourne, Australia).

Merrifield, J. (1996). Examining the language learning strategies used by french adult learners. (Master's thesis, Aston University, Birmingham, England).

Mistar, J. (2011a). Learning strategies by Indonesian senior high school EFL learners. Korea TESOL Journal, 10(1), 52-74.

Mistar, J. (2011b). A study of the validity and reliability of self-assessment. TEFLIN Journal, 22(1), 45-58.

Mistar, J., Zuhairi, A., \& Umamah, A. (2014). Strategies of learning speaking skill by senior high school EFL learners in Indonesia. Paper presented at the 10th International TESOL Conference, Manila.

Mochizuki, A. (1999). Language learning strategies used by Japanese university students. RELC Journal, 30(2), 101-113.

Monjezi, M. (2014). The effects of proficiency and gender on the compliments and compliment responses made by Iranian EFL learners. International Journal of Language Learning and Applied Linguistics World, 5(1), 625636.

Moriam, Q. M. (2005). Speaking strategy use by the EFL students in Japan and Bangladesh. Journal of International Development and Cooperation, 12(1), 47-61.

Nakatani, Y. (2006). Developing an oral communication strategy inventory. The Modern Language Journal, 90(2), 151-168. 
Novitasari, H. (2009). Language learning strategies applied by speaking class students. (Undergraduate thesis, Soegijapranata Catholic University, Semarang, Indonesia).

Oxford, R. L. (1990). Language learning strategies: What every teacher should know. New York: Newbury House Publishers.

Oxford, R. L., \& Ehrman, M. E. (1995). Adult's language learning strategies in an intensive foreign language program in the United States. System, 23(3), 359-386.

Thomson, I., \& Rubin, J. (1996). Can strategy instruction improve listening comprehension? Foreign Language Annals, 29(3), 331-342.

Umamah, A. (2008). A study on the speaking strategies applied by EFL learners at English department of Unisma. (Undergraduate thesis, Islamic University of Malang, Indonesia).

Wahyuni, S. (2013). L2 speaking strategies employed by Indonesian EFL tertiary students across proficiency and gender. (Ph.D thesis, University of Canberra, Australia).

Wharton, G. (2000). Language learning strategy use of bilingual foreign language learners in Singapore. Language Learning, 50(2), 203-243.

Yan, H. (2009). Empirical study on relations between gender differences and English vocabulary and the overall proficiency level. Asian Social Science, 5(10), 109-114. 